\title{
IDENTIFICATION OF GENETIC IMPROVEMENT USING GENETIC MARKERS IN SOME LOCAL RABBIT STRAINS: 1. EFFECT OF GENETIC VARIATION
} Sheteifa M. A. M. ; Ola A. Galal* ; Ragaa E. Abd El-Karim and F. A. Tawfeek

Animal Production Res. Inst., Agric. Res. Center, Ministry of Agric., Dokki, Egypt

*Genetics Dept., Fac. Agric., Kafrelsheikh Univ., 33516 Kafr El-Sheikh, Egypt.

\begin{abstract}
Genetic variations were detected in four rabbit genotypes; APRI line, NewZealand White (NZW), Baladi Black (BB) and Gabali (GAB) breeds. Blood samples were taken from ten doe rabbits from APRI, NZW and BB in addition to seven does from GAB. Isozymes (esterase and peroxidase) and SDS-protein markers were used to detect the genetic variations within the four genotypes. RAPD-PCR analysis using six random arbitrary primers were employed to assess the genetic variations and phylogenetic relationships among the four genotypes. Results showed that there are a variation in both of protein and isozymes activity levels. Esterase profiles showed higher percentage of polymorphism $(67.21 \%)$ than peroxidase $(34.78 \%)$ and SDSprotein profiles $(39.11 \%)$ within the studied genotypes. Overall mean of the genetic similarity within the studied genotypes based on all biochemical markers were 0.81 (APRI), 0.91 (NZW), $0.89(\mathrm{BB})$ and 0.86 (GAB), which indicated high homogeneity within each genotype. The polymorphism percentage based on overall RAPD primers was $35.44 \%$ among the four genotypes, which suggest a kind of genetic diversity among the rabbit genotypes. From the dendrogram tree, both BB and GAB appeared to be closely related, while the APRI was the most different. The obtained results could have a great impact in rabbit breeding programs, such as selection or crossing programs.
\end{abstract}

Keywords: Rabbit, genetic diversity, SDS-PAGE, isozymes, RAPD-PCR.

\section{INTRODUCTION}

Rabbit is a livestock animal has its importance as supplier of meat, and it is widely accepted thought out the world for human consumption (Colin and Lebas, 1996). Assessment of genetic diversity form an integral part of any successful breeding program. The genetic diversity found in domestic breeds allows breeders to develop new characteristics in response to changes in environment, diseases or market conditions. A considerable number of genetic diversity studies for several livestock species have been carried out during recent years by research teams from all over the world (Cítek and Rehout, 2001; Rendo et al., 2004; Zho et al., 2005; Cinkulov et al., 2008, and Loukou et al., 2009).

The genetic variability can be assessed by genetic markers. Genetic markers are distinguished on three principle classes: based on visually evaluated traits (morphological and productive traits), based on gene product (biochemical markers), and founded on DNA analysis (molecular markers). 
The idea of using the genetic markers came forward very early in the scientific studies (Sax, 1923) but the development of electrophoretic separation of protein (Markert and Moller, 1959) and molecular markers (Botstein et al., 1980; Williams et al., 1990 and Jaccoud et al., 2001) made better the comprehensions in biological based sciences. Morphological features are indications of the genotype but are represented by only a few loci because there are not a large enough number of characters available. Moreover, they can also be affected by environmental factors and growth practices. To overcome the limitations associated with morphological markers, various biochemical and molecular marker techniques have come up in recent years (Teneva and Petrović, 2010).

Protein electrophoresis has been an effective technique for the detection of genetic polymorphism for over three decades. The polymorphism of blood protein markers gives some useful information in studies of animal breeding such as the relationships among breeds and their evolution. Variation in proteins reflects changes in the genes that code for them. This has been widely used in studying genetic diversity (Hames and Rickwood, 1990 and Atta et al., 2009). In this case, many researchers employed classical biochemical polymorphic markers such as polymorphic proteins (Deza et al., 2000; Machado et al., 2000 and Han and Yuzhu, 2002) and isozymes (Cengiz and Asal, 2000; Menrad et al., 2002 and Nyamsamba et al., 2003) to characterize and estimate the genetic diversity within and among livestock breeds.

On the other hand, RAPD (random amplified polymorphic DNA) is a technology of molecular genetics marker. It was established through PCR technology to test polymorphic DNA of genome by Williams et al. (1990) and Welsh et al. (1990). As the technology is simple, quick, sensitive, little DNA consumption and low cost, it has been widely utilized in genetics analysis in animal, plant and microorganism and shown good results in population genetics diversity, genetic map construction, gene mapping and forecast of genetic distance and heterosis (Huber et al., 2002). RAPD technology is principally used to study blood relationship between varieties/species in the rabbit. For instance, Yang Liping et al. (2000) analyzed three domestic rabbit varieties/species; Teneva et al., (2005) analyzed far or close evolutionary blood relationship among five rabbit populations; Chen et al. (2005) analyzed genetic relationship among three varieties/species and (Rangoju et al., 2007) assess the genetic variability and phylogenetic relationship among rabbit breeds.

Therefore, the present investigation was aimed to estimate the genetic diversity within (using isozymes and SDS-protein markers) and among (using RAPD markers) four rabbit genotypes in Animal Production Research Institute. 


\section{MATERIALS AND METHODS}

\section{Animals :}

Four different genetic groups of rabbit: one line Animal Production Research Institute (APRI) and three breeds: New-Zealand White (NZW), Baladi Black (BB) and Gabali (GAB) were used in the present study.

Animal Production Research Institute (APRI) line: This line was developed in the Animal Production Research Institute in Egypt. The first step of synthesis was to get $\mathrm{F} 1$ coming from crossing Red Baladi bucks with does of $\mathrm{V}$ line. The procedure continued getting F1, F2, F3 and so on. After F3, the animals were named APRI line. In this line, the proportion of genes is $50 \%$ from line $V$ and $50 \%$ from Red Baladi. The line $V$ is housed at the Sakha and Gimmiza Stations and selected for litter weight at weaning. The Institute keeps also the APRI line at Sakha station and was selected with the same criterion that was in $\mathrm{V}$ line.

New Zealand White (NZW): A foreign rabbit breed actually originated in the United States and wide spread overall the world.

Baladi Black (BB): Egyptian local breed that, after their formation, have not followed by a program of genetic improvement (Khalil, 2002).

Gabali (GAB): Egyptian local breed. The breed is a medium sized breed and used mainly for meat. Yellowish-brown with black hairs spread all over the body with soft fur. Black hairs are intense on tail. they are two strains within breed: Gabali of Sinai, Gabali of the western desert (Khalil, 1999) Sinai and eastern and western (in the north coast belt) deserts of Egypt. They are raised by the Bedouins for their food. They are referred to by Mahmoud (1938) as Native Egyptian rabbits. They were also raised in some western Giza Governorate areas by individual persons. recently studied by Afifi (2002) and Iraqi et al. (2007), showing very promising results.

A total of thirty seven doe rabbits were randomly selected for the trial; ten dose from each of APRI line, NZW and BB breeds, in addition, seven does from GAB breed. All were taken from Sakha station.

\section{Recorded traits:}

Four reproductive performance traits were measured for the selected individuals in each rabbit genotype. The traits which were Measured are: litter size at birth and weaning, litter weight at weaning and fertility rate.

\section{Biochemical analyses:}

Blood samples collection:

Approximately $1.5 \mathrm{ml}$ blood sample was collected from each doe (from the central artery vein of the ear) in centrifuge tubes contained heparin sodium as anticoagulant reagent. Plasma has been obtained by centrifugation at $5000 \mathrm{rpm}$ for $15 \mathrm{~min}$ at $4^{\circ} \mathrm{C}$ and the plasma protein (supernatant) was transferred to clean tubes and stored at $-20^{\circ} \mathrm{C}$ until the time of electrophoretic analysis.

Isozymes:

The collected blood plasma samples were used for detecting isozyme variation among the selected individuals within each rabbit genotype, at the genetics Dept., Fac., of Kafrelsheikh Univ., Kafr El-Sheikh, Egypt. Two 
isozyme systems (i.e., esterase and peroxidase) were applied in nondenaturing polyacrylamide gel electrophoresis. Esterase isozymes were localized on the gel using $\alpha$ and $\beta$-naphthyl acetate (40 mg of each) and 250 mg Fast blue dissolved in $98 \mathrm{ml}$ of $0.1 \mathrm{M}$ phosphate buffer ( $\mathrm{pH}$ 6.5). However, peroxidase isozyme patterns was determined using the staining solution composed of $250 \mathrm{mg}$ of benzidine dihydro chloride (moistened with 4 drops of glacial acetic acid ) in $100 \mathrm{ml} \mathrm{H} 2 \mathrm{O}$ and 10 drops of $1 \% \mathrm{H} 2 \mathrm{O} 2$ was added immediately before being used according to Scandalios (1964).

\section{SDS-Protein:}

The same collected samples were used to detect protein polymorphism within each genotype. Samples were applied to $12 \%$ SDS-polyacrylamid gel electrophoresis. Gel preparation, electrophoresis conditions, staining and destaining gels were done according to Laemmli (1970). Protein fractionations were performed exclusively on vertical slab gel using prestained high molecular weight standard marker with molecular weight ranged from 175 to $15 \mathrm{KDa}$. The stained gels were photographed and examined for the presence and absence of visualized bands.

\section{Molecular analysis:}

\section{DNA extraction:}

Genomic DNA was isolated from approximately $200 \mu \mathrm{l}$ of blood samples according to manufacture instruction (Biospin whole blood genomic DNA extraction kit, Cat. BSC06S1). The genomic DNA of each collected samples of each genotypes was mixed in a bulked sample according to Lukyanov et al. (1996).

\section{Random amplified polymorphic DNA (RAPD)-PCR :}

Six decamer RAPD primers (OP-A9, B5, B7, B8, B10 and B14) were screened on pooled rabbit DNA. All primers were purchased from Bio Basic Inc, Canada. The list of primers and their sequences are presented in Table (1).

Table (1): List of random amplified polymorphic DNA (RAPD) primers and their nucleotide sequence.

\begin{tabular}{|l|l|}
\hline Primer code & Sequence $\left(5 \rightarrow 3^{\prime}\right)$ \\
\hline OP-A9 & GGGTAACGCC \\
\hline OP-B5 & TGCGCCCTTC \\
\hline OP-B7 & GGTGACGCAG \\
\hline OP-B8 & GTCCACACGG \\
\hline OP-B10 & CTGCTGGGAC \\
\hline OP-B14 & TCCGCTCTGG \\
\hline
\end{tabular}

The optimization of PCR (Polymerase Chain Reaction) conditions for each primer were performed in a $25 \mu \mathrm{l}$ reaction volume including $0.5 \mu \mathrm{l}$ of isolated DNA template. Final concentrations were $1 \mathrm{x}$ buffer $(\mathrm{Mg} 2+$ free), 1.5 $\mathrm{mM} \mathrm{MgCl2,} 200 \mu \mathrm{M}$ dNTPs mix, 800 nM primer, $1 \mathrm{U}$ Taq DNA Polymerase (ROVALAB, Germany). Amplifications was carried out in a thermal cycler. The initial amplification program started with denaturation at $94^{\circ} \mathrm{C}$ for $5 \mathrm{~min}$, followed by 35 cycles consisting of $30 \mathrm{~s}$ of denaturation at $94^{\circ} \mathrm{C}, 45 \mathrm{~s}$ of annealing at $30^{\circ} \mathrm{C}$ and $1.5 \mathrm{~min}$ of elongation at $72^{\circ} \mathrm{C}$. The program ended with a final elongation step at $72^{\circ} \mathrm{C}$ for $2 \mathrm{~min}$. Amplification products were 
separated on $1.5 \%$ agarose gel, stained with ethidium bromide and visualized under ultraviolet light. A known DNA ladder (50 bp DNA Ladder ready-to-use, Cat-no: 300003, GeneON) was run against the PCR products.

\section{Data analyses:}

\section{Quantitative traits:}

The recorded data for reproductive traits were subjected to a one-way ANOVA using SPSS program. Significance level adopted was $95 \%$. Results were expressed as mean \pm standard errors (SE).

\section{Genetic relationships}

The data generated from isozymes (native gel) and protein banding patterns, in addition; the banding patterns of the six RAPD primers were introduced to SPSS package program according to binary values of (1) and (0) for the presence and absence of bands, respectively. The genetic similarity within each genotype was assessed based on biochemical analyses on the basis of the Dice similarity coefficient. The phylogenetic relationship among rabbit genotypes was conducted based on the similarity coefficients of RAPD primers data using UPGMA analysis.

\section{RESULTS AND DISCUSSION}

\section{Reproductive performance Analyses:}

Data describing the reproductive performance in the four rabbit genotypes are presented in Table (2). The objective of the present study is not to compare performances between them, but to know the level and range of variation of the traits among the four genotypes. Data showed no significant differences in all studied traits among the four genotypes, except the litter size at weaning, which showed significant differences between APRI and NZW and BB and GAB. Similarly, Argente et al. (2010) did not find relevant differences in fertilization rate (FR) between two lines of rabbits divergently selected by uterine capacity. A similar FR was also found in previous results in the same lines (Moce et al., 2004 and Peiro et al., 2007) and by other authors using other lines with different embryo survival (GarciaXimenez and Vicente, 1992; Bolet and Theau-Clement, 1994).

Table (2): Means and SE of reproductive performances traits of different rabbit genotypes.

\begin{tabular}{|c|c|c|c|c|}
\hline \multirow{2}{*}{ Genotype } & \multicolumn{2}{|c|}{ Litter size /doe } & \multirow{2}{*}{$\begin{array}{l}\text { Litter weight/doe at } \\
\text { weaning }(\mathrm{g})\end{array}$} & \multirow{2}{*}{ Fertility rate $(\%)$} \\
\hline & at birth & at weaning & & \\
\hline APRI $n=10$ & $7.20 \pm 0.99$ & $5.60 \pm 1.06^{a}$ & $360.00 \pm 49.47$ & $57.50 \pm 10.57$ \\
\hline NZW n=10 & $5.50 \pm 0.92$ & $4.55 \pm 0.78^{a}$ & $227.50 \pm 38.81$ & $67.50 \pm 9.89$ \\
\hline $\mathrm{BB} n=10$ & $5.20 \pm 1.56$ & $1.95 \pm 0.97^{b}$ & $260.00 \pm 78.19$ & $42.50 \pm 10.57$ \\
\hline GAB $n=7$ & $4.75 \pm 2.49$ & $0.25 \pm 0.25^{b}$ & $237.50 \pm 124.37$ & $62.50 \pm 16.14$ \\
\hline
\end{tabular}

Different letters indicate significant differences $(P<0.05)$ between mean values. 


\section{Genetic variation within rabbit genotypes based on biochemical} markers :

Isozymes and SDS-PAGE polymorphism within rabbit genotypes :

Isozymes are not only quicker and less labor intensive than traditional methods but also more reliable since the expression of isozymes loci are codominant (Ryan and Scowcroft, 1987 and Arus, 1993). In the present study, two isozyme systems of esterase and peroxidase were used to detect the genetic variability within the four studied rabbit genotypes (Fig. 1 and 2). One band has assumed to be corresponded to one locus (allele).
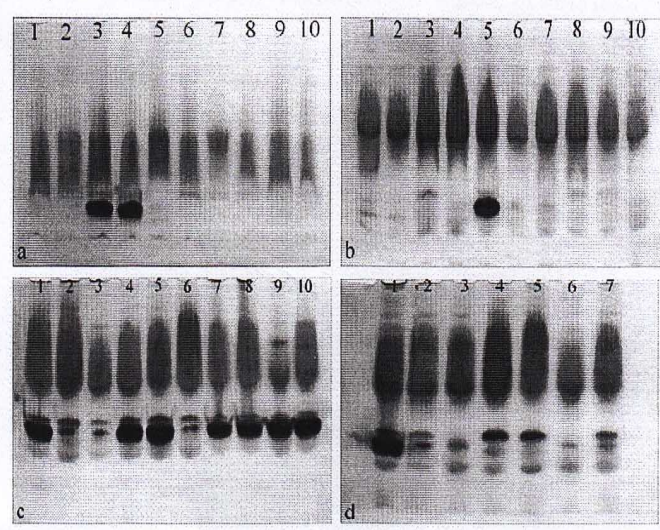

Fig. (1): Esterase electrophoretic patterns of the four rabbit genotypes; APRI (a), $\mathrm{NZW}(\mathrm{b}), \mathrm{BB}(\mathrm{c})$ and $\mathrm{GAB}(\mathrm{d})$.

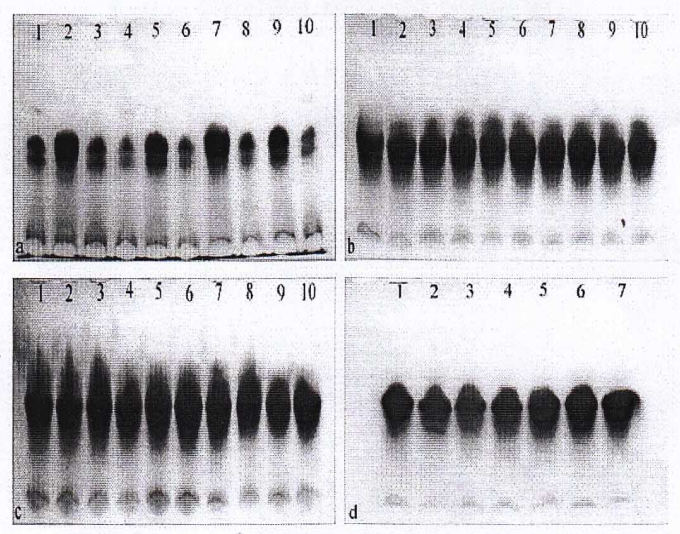

Fig. (2): Peroxidase electrophoretic patterns of the four rabbit genotypes; APRI (a), NZW (b), BB (c) and GAB (d). 
The electrophorotic patterns of esterase enzyme reveled marked polymorphism within the studied rabbit genotypes as shown in Table (3). The four genotypes contained 61 alleles, APRI line contained 14 alleles, and the two breeds NZW and BB had 15 alleles, while GAB breed contained the highest number of esterase alleles (17 alleles). Percentage of polymorphic loci within the four genotypes ranged from 53.33 to $85.71 \%$. APRI line showed the highest polymorphic bands (85.71\%); 12 out of the 14 loci scored were polymorphic, while NZW breed revealed the lowest polymorphic bands (53.33\%); 8 out of the 15 loci scored were polymorphic.

Deza et al. (2000) studied esterase variations among some native goats from different locations and found individual differences among goat samples using these isozyme marker. In this respect, El-Seoudy et al. (2005) reported that esterase had a value to discriminate among goat populations. Also, Anous et al. (2008) used esterase isozymes to detect individual variations within each of three Egyptian goat populations.

Concerning peroxidase marker, levels of polymorphism slightly differed among genotypes. A total of six loci ranged from 4-6 were detected for APRI line as well as NZW and GAB breeds. However, out of these loci, four loci were monomorphic or present in all individuals and only two loci were polymorphic (33.33\% polymorphism). While, the profile of BB breed blood plasma exhibit only five loci ranged from 3-5 with $40.00 \%$ polymorphism. These results indicated that this enzymatic system could not be used alone to differentiate among the tested individuals. Also, Nyamsamba et al. (2003) could not obtain any clear genetic differences among eight native goat populations by studying their isozyme variations.

The protein banding patterns of the four rabbit genotypes revealed wide variations of different bands as shown in Table (3) and Fig. (3). The maximum number of bands ( 55 bands) were found in GAB breed, while the minimum number of bands (38 bands) was obtained in BB breed, which showed the lowest polymorphic ratio $(21.05 \%)$. The total number of bands of BB breed was only 38 bands, out of them 30 bands were monomorphic. These bands which were observed in all samples are common bands in this breed. On the other hand, the highest polymorphic ratio was found to be $75.61 \%$ in APRI line. While, NZW and GAB breeds revealed moderate polymorphic bands $(33.33 \%$ and $29.09 \%$, respectively). Recently many authors have been reflected this point such as Anous et al. (2008), who assessed the genetic structure within each of three Egyptian goat populations using serum protein marker. They concluded that protein analysis is a sensitive method for studying the genetic structure of goat populations.

Concerning all biochemical markers, most of polymorphisms were due to esterase alleles. Esterase had 20 monomorphic loci and 41 polymorphic loci $(67.21 \%$ polymorphism) indicating high esterase variation. However, peroxidase exhibited the lowest level of polymorphism among the studied genotypes, only 8 out of 23 loci scored were polymorphic (34.78\%) and 15 loci were monomorphic indicating low peroxidase variation. A total of 179 bands were generated using protein analysis, 70 bands were polymorphic (39.11\%), and however 109 bands were monomorphic (common) for all genotypes indicating moderate protein variation. The 
present results suggested that esterase marker was a powerful method to evaluate genetic variability within rabbit genotypes. Similar result was observed by El-Seoudy et al. (2008), who detected lower genetic differences using native protein marker than six isozyme systems within the examined animals of three Egyptian camel breeds.

Table (3): Polymorphism percentages generated by esterase and peroxidase isozymes as well as protein marker in the four rabbit genotypes.

\begin{tabular}{|c|c|c|c|c|c|}
\hline Genotype & $\begin{array}{c}\text { Total } \\
\text { bands } \\
\text { (n) }\end{array}$ & $\begin{array}{l}\text { Range of } \\
\text { bands } \\
\text { products }\end{array}$ & $\begin{array}{l}\text { Monomorphic } \\
\text { bands (n) }\end{array}$ & $\begin{array}{l}\text { Polymorphic } \\
\text { bands (n) }\end{array}$ & Polymorphism (\%) \\
\hline \multicolumn{6}{|c|}{ Esterase marker : } \\
\hline APRI $n=10$ & 14 & $5-10$ & 2 & 12 & 85.71 \\
\hline NZW $n=10$ & 15 & $9-12$ & $\overline{7}$ & 8 & 53.33 \\
\hline BB $n=10$ & 15 & $8-14$ & 6 & 9 & 60.00 \\
\hline GAB $n=7$ & 17 & $8-14$ & 5 & 12 & 70.59 \\
\hline Total & 61 & $5-14$ & 20 & 41 & 67.21 \\
\hline \multicolumn{6}{|c|}{ Peroxidase marker: } \\
\hline APRI $n=10$ & 6 & $4-6$ & 4 & 2 & 33.33 \\
\hline NZW $n=10$ & 6 & $4-6$ & 4 & 2 & 33.33 \\
\hline $\mathrm{BB} \quad \mathrm{n}=10$ & 5 & $3-5$ & 3 & 2 & 40.00 \\
\hline GAB $n=7$ & 6 & $4-6$ & 4 & 2 & 33.33 \\
\hline Total & 23 & $3-6$ & 15 & 8 & 34.78 \\
\hline \multicolumn{6}{|c|}{ Protein marker : } \\
\hline APRI $n=10$ & & $23-33$ & 10 & 31 & 75.61 \\
\hline$N Z W \quad n=10$ & & $37-42$ & 30 & 15 & 33.33 \\
\hline BB $n=10$ & & $32-38$ & 30 & 8 & 21.05 \\
\hline GAB $n=7$ & & $46-50$ & 39 & 16 & 29.09 \\
\hline Total & & $23-50$ & 109 & 70 & 39.11 \\
\hline
\end{tabular}

APRI=Animal Production Research Institute, NZW=New Zealand White, BB=Baladi Black and $\mathrm{GAB}=$ Gabali

\section{Genetic similarity within rabbit genotypes:}

Ranges and averages of similarity values within each of the four genotypes based on isozymes and protein markers are listed in Table (4). Average of similarity indices reflects the range of homogeneity and inbreeding within each tested genotypes. Esterase and protein markers reveled that APR1 line had the lowest similarity average among the ten selected individuals within the line. These results are in constant with the results of polymorphism which showed the highest polymorphism in APRI line based on esterase and protein markers. Based on esterase marker, the highest genetic similarity average was found within NZW breed (0.86), while the lowest one was observed within APRI line (0.73). However, BB and GAB breeds showed genetic similarity averages, being 0.80 and 0.77 , respectively. Concerning peroxidase marker, all genotypes revealed high similarity averages ranging from 0.88 (GAB) to 0.93 (NZW), which may indicate high homogeneity within each genotype. Using protein marker gave also, high similarity averages within the tested genotypes. However, the lowest genetic similarity averages were found within APRI line $(0.80)$.

The general mean of the genetic similarity within the studied genotypes based on all biochemical markers, overall mean was 0.91 (NZW), 0.89 (BB), 
0.86 (GAB) and 0.81 (APRI), which indicated high degree of homogeneity and inbreeding within each one of the four studied genotypes. It is clear that NZW had the highest average value followed by BB and GAB breeds, while APR1 line had the lowest value and this may reflect a higher degree of inbreeding in the three breeds in comparison with APRI line.

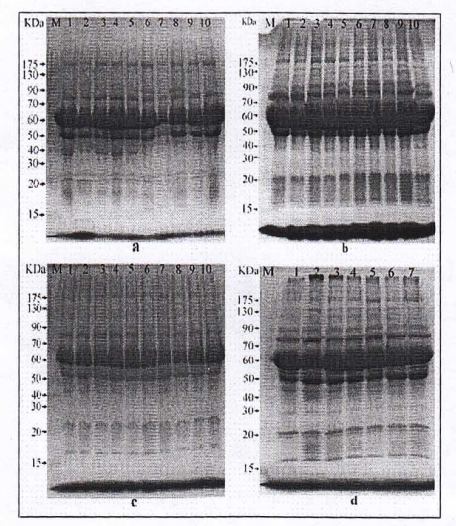

Fig. (3): The protein banding patterns of the four rabbit genotypes; APRI (a), NZW (b), BB (c) and GAB (d).

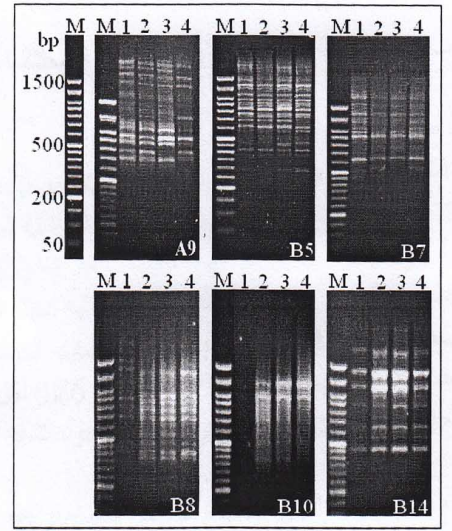

Fig. (4): DNA polymorphism using RAPD markers for the four rabbit genotypes; APRI (lane 1), NZW (lane 2), BB (lane 3) and GAB (lane 4). M refers to the DNA ladder. 
Table (4): Similarity ranges and averages within four genotypes based on different biochemical markers.

\begin{tabular}{|l|c|c|c|c|c|c|c|}
\hline \multirow{2}{*}{ Genotype } & \multicolumn{2}{|c|}{ Esterase marker } & \multicolumn{2}{c|}{ Peroxides marker } & \multicolumn{2}{c|}{ Protein marker } & Overall \\
\cline { 2 - 7 } & Range & Average & Range & Average & Range & Average & mean \\
\hline APRI & $0.43-0.90$ & 0.73 & $0.80-1.00$ & 0.90 & $0.64-0.96$ & 0.80 & 0.81 \\
NZW & $0.70-1.00$ & 0.86 & $0.80-1.00$ & 0.93 & $0.87-1.00$ & 0.93 & 0.91 \\
BB & $0.67-0.95$ & 0.80 & $0.75-1.00$ & 0.91 & $0.91-1.00$ & 0.95 & 0.89 \\
GAB & $0.61-0.88$ & 0.77 & $0.80-1.00$ & 0.88 & $0.90-0.99$ & 0.94 & 0.86 \\
\hline
\end{tabular}

Genetic variations among rabbit genotypes based on RAPD markers: Polymorphism among rabbit genotypes:

RAPD amplifies the target genomic DNA with short, arbitrary primers (commonly $10 \mathrm{bp}$ ) in a PCR reaction, and can be used to produce relatively complicated DNA profiles for detecting amplified fragment length polymorphisms between organisms. Since the arbitrary primers complement different parts of the genomic DNA, PCR products will differ in number and size (polymorphism). RAPD-PCR fingerprints have been successfully used in defining genetic diversity among different species (i.e. the RAPD-PCR was used to generate specific fingerprint patterns between different species of horse, buffalo, beef, venison, rabbit, and kangaroo (Yang et al., 2013). In this study, six primers were used to assess the genetic variability among the four rabbit genotypes which generated a total of 269 DNA fragments. Twenty eight bands (35.44\%) were polymorphic, however, fifty one bands were monomorphic (common) for all genotypes. The highest level of polymorphism (100\%) was observed in primer OP-B10; since the APRI genotype didn't give any band reaction with this primer while the other three genomes gave two distinct bands at least. However, the lowest level of polymorphism was $20 \%$ primer OP-B14 as shown in Table (5).

Table (5): Level Polymorphism among the four genotypes based on RAPD analysis.

\begin{tabular}{|l|c|c|c|c|c|c|c|c|}
\hline \multirow{2}{*}{ Primer } & \multirow{2}{*}{ TAF } & \multirow{2}{*}{ PB } & \multirow{2}{*}{ MP } & \multirow{2}{*}{ P\% } & \multicolumn{4}{c|}{ AF } \\
\cline { 6 - 9 } & & & & & APRI & NZW & BB & GAB \\
\hline OP-A9 & 17 & 7 & 10 & 41.18 & 16 & 17 & 15 & 12 \\
\hline OP-B5 & 19 & 6 & 13 & 31.58 & 16 & 17 & 16 & 14 \\
\hline OP-B7 & 16 & 4 & 12 & 25.00 & 16 & 13 & 13 & 14 \\
\hline OP-B8 & 14 & 6 & 8 & 42.86 & 11 & 10 & 11 & 12 \\
\hline OP-B10 & 3 & 3 & 0 & 100.0 & 0 & 3 & 3 & 3 \\
\hline OP-B14 & 10 & 2 & 8 & 20.00 & 8 & 10 & 9 & 10 \\
\hline Total & 79 & 28 & 51 & 32.44 & 67 & 70 & 67 & 65 \\
\cline { 5 - 9 } & & & & & \multicolumn{4}{|c|}{269} \\
\hline
\end{tabular}

TAF: Total amplified fragment, PB: Polymorphic bands, MP: Monomorphic bands, P\%: Polymorphism \% and AF: Amplified fragment.

\section{Genetic relationships among rabbit genotypes:}

The obtained variations from RAPD analysis was used to construct a genetic distance tree (Fig. 5) based on the amount of shared alleles between all pairs of individuals. The results indicated that BB genotype was closely related with GAB breed, while the APRI genotype was the most different. This may due to fact that BB and GAB are Egyptian genotypes. This results is in consistent with performance results for litter size at weaning. This was in 
agreement with Keliang et al. (2008), who found that RAPD marker correlated with reproductive performances in Rex rabbit. These results indicated that RAPD primers revealed a kind of genetic diversity among these genotypes, which suggested that RAPD markers can be used as a tool to understand the genetic variability and phylogenetic relationship among rabbit genotypes. Knowledge of the genetic distances among different genotypes is very useful for genetic improvement (Ceron and Angel, 2001). Similar finding were obtained by Mamuris et al., (2002), who found higher genetic identity within rabbit population as compared to populations of brown hares from different regions.

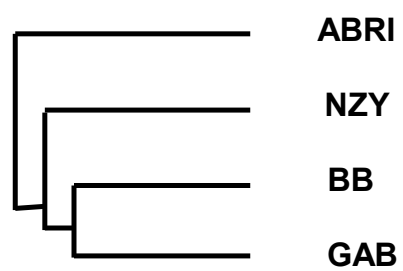

Fig, (5): Dendrogram showing genetic relationships among the four rabbit genotypes based on similarity indices derived from RAPD analysis.

Conclusion: Based on the forgoing results, there are closely relationships among some rabbit breed and higher genetic diversity among others, which cold gave a genet impact in rabbit breeding programs for new rabbit lines.

\section{REFERENCES}

Afifi, E.A. (2002). The Gabali rabbits. In: Khalil M.H.and Baselga, M. (Eds). Rabbit Genetic Resources in Meditei-ranean Countries. Options Mediterranennes, Series B, No 38, 51-64.

Anous, M.R.; M.A. Rashed; H.R. Motaoa; M.H. Sadek; Y.M. Saad; M.A. Osman and E.M. Shath, (2008). Identification of fecundity gene in Egyptian goats using genetic markers. I. Biochemical polymorphic markers. Egyptian J. Genetic and Cytol., 37:83-94.

Arus, P. (1993). Genetic purity of commercial seed lots. In: Tanksley, S. D. and Orton, T. J. (Eds.) Isozymes in plant genetics and breeding, Part A, pp. 415-423. Elsevier Sci. Publishers B. V. Amsterdam.

Atta, A.H.; E.S. Ahmed; M.FI. Sadek and A.A. Amin (2009). Development of Molecular Markers for Detecting Genetic Relationships Within and Among Six Egyptian Buffalo Locations. Global Veterinaria, 3 (4): 341347.

Argente, M. J., M. Merchan; R. Peiro; M. L. Garcia; M. A. Santacreu; J. M. Folch and A. Blasco (2010). Candidate gene analysis for reproductive traits in two lines of rabbits divergently selected for uterine capacity. Journal of animal science, 88: 828-836. 
Bolet, G. and A. Theau-Clement (1994). Fertilisation rate and preimplantation embryonic development in two rabbit strains of different fecundity, in purebreeding and crossbreeding. Anim. Reprod. Sci. 36:153-162.

Botstein, D.; R.L.White; M. Skolnik and R.W. Davis, (1980). Construction of a genetic linkage map in man using restriction fragment length polymorphisms.

Am. J. Hum. Genet., 32, 314-331.

Cengiz, E. and S. Asal (2000). Blood biochemical polymorphism in Angora goat breed. Egyptian J. Animal Production, 37: 31-36.

Ceron, A. and F. Angel (2001). Genetic diversity in sugarcane hybrids in Colombia measured using molecular markers. Proc. Int. Soc. Sugarcane Technol. Of North America, 24: 626.

Chen, L.; Z. Weibo and Y. Huachun, (2005). RAPD analysis of genetics traits in WHBE rabbit. Journal of Zhejiang University (Edition of Life Science), 31(4): 493-498.

Cinkulov, M.; Z. Popovski; K, Porcu; B. Tanaskovska; A. Hodz Ic' H. Bytygi; H., Mehmeti; M. V. Djedovic' R. Hoda A. Trailovic R. Brka M. Markovic B. Vaz Ic B. Vegara M. Olsaker I. and J. Kantanen, (2008). Genetic diversity and structure of the West Balkan Pramenka sheep types as revealed by microsatellite and mitochondrial DNA analysis. J. Anim. Breed. Genet., 125, 417-426

Citek, J. and V. Rehout (2001). Evaluation of the genetic diversity in cattle using microsatellites and protein markers. Czech J. Anim. Sci., 46, 393400.

Colin, M. and F. Lebas (1996). Rabbit meat production in the world. A proposal for every country. In Proc.: $6^{\text {th }}$ World Rabbit Congr, Toulouse, France, 323-330.

Deza, C.; O.T. Perez; C.N. Gardenal; I. Varel; M. Villar; S. Rubiaies and C. Barioglio, (2000). Protein polymorphism in native goats from General Argentina. Small Ruminant Res., 35: 195-201.

El-Seoudy, Alia A.; M. Nermin Abdel Gawad; M. Asmaa Abu Shady and A.Z.E. Abdelsalam, (2005). Biochemical and molecular genetic characterization of some Egyptian goat breeds. Egyptian. J. Genetic and Cytol., 34: 63-79.

El-Seoudy, Alia A.; A.Z.E. Abdelsalam; E.E. Tharwat and A.M. Fatma Abdelsalam, (2008). Molecular genetic identification of some camel breeds in Egypt. Egyptian J. Genetic and Cytol., 37:191-208.

Garcia-Ximenez, F. and J.S. Vicente, (1992). Effect of ovarian cystic or haemorrhagic follicles on embryo recovery and survival after transfer in hCG-ovulated rabbits. Reprod. Nutr. Dev. 32:143-149.

Hames, B.D. and D. Rickwood, (1990). Gel electrophoresis of proteins-A practical approach. $2^{\text {nd }}$ edition. IRL Press at Oxford University Press, Oxford, England.

Han, J. and L. Yuzhu, (2002). Study on polymorphism of transferring of native Zhongwei goats, crossbreeds of AngoraxZhongwei (F1) and Angorax F1 proceeding of $7^{\text {th }}$ world congress on genetics applied to livestock production, Aug. 19-23, Montpellier, France. 
Huber, B.S.; D.V. Allred; J.C. Carmen; D.D. Frame; D.G. Whiting; T.R. Cryan, Olson; P.J. Jackson; K. Hill; M.T. Laker and R.A. Robison, (2002). Random amplified polymorphic DNA and amplified fragment length polymorphism analyses of Pasteurella multocida isolates from fatal fowl cholera infections. J. Clin. Microbiol. 40: 2163-2168.

Iraqi, M.M.; M.E. Shenana and M. Baselga, (2007). Some factors affecting productive and milk composition characters in a crossbreeding experiment involving Gabali and V- line rabbits in Egypt. World Rabbit Sci., 15(3), 151-159.

Jaccoud, D.; K. Peng; D. Feinstein and A. Kilian (2001). Diversity arrays: a solid state technology for sequence information independent genotyping. Nucleic

Acids Res., 29, 25.

Keliang, R.; L. Yanping; H. Dongchang; W. Xinsheng; Z. Ping; L. Quanzhong; Z. Lijun; Z. Shenghua and C. Liang, (2008). Study on relationship of rex rabbit rapd marker and reproductive performances. $9^{\text {th }}$ World Rabbit Congress - June 10- 13, 2008 - Verona - Italy

Khalil, M.H. (1999). Rabbit genetic resources of Egypt. Animal Genetic Resources, 26: 95-111.

Khalil, M.H. (2002). The Baladi rabbits. In Khalil M.H. and M. Baselga (Eds). Rabbit Genetic Resources in Mediterranean Countries. Options Mediterranennes, Series B, N. 38, 37-50.

Laemmli, U. K. (1970). Clavage of structural protein during assembly of head bacteriophage T4. Nature, 227: 680-685.

Lukyanov, K.A.; M. Matz; E. Bogdanova; N.G. Gurskaya and S.A. Lukyanov, (1996). Molecule by molecule PCR amplification of complex DNA mixtures for direct sequencing: an approach to in vitro cloning. Nucleic Acids Res., 24: 2194-2195.

Loukou, N.E., C.V. Yapi-Gnaore; G.Y. Toure; G. Coulibal; X. Rognon and B. Kayang (2009). Evaluation de la diversité des poulets traditionnels de deux zones agroécologiques de Côte d'lvoire à l'aide de marqueurs microsatellites. Journal of Animal \& Plant Sciences, 5, Issue 1, 425436.

Machado, T.M.M.; M.L.S.P. Igarashi; E.P.B. Conte and J. A. Ferro, (2000). Genetic diversity within the goat populations of Brazil. Proceeding of $7^{\text {th }}$ International Conference on goats, France, 15-21 May, p. 958-960.

Mahmoud, I.N. (1938). Bases of Veterinary Medicine, 2nd edn. Cairo University, Egypt (in Arabic).

Mamuris, Z.; A.I. Sfougaris; C. Stamatis and F. Suchentrunk, (2002). assessment of genetic structure of Greek brown hare (Lepus europaeus) populations based on variation in random amplified polymorphic DNA (RAPD). Biochem. Genet., 40: 323-338.

Markert, C.L; F. Moller (1959). Multiple forms of enzymes: Tissue, ontogenetic and species specific patterns. Proc. Natl. Acad. Sci. USA, 45, 753-763. 
Menrad, M.; C.H. Stier and C.F. Gall, (2002). A study on the Changthangi Pashmina and the Bakew wall goat breeds in Kashmir I. Analysis of blood protein polymorphism and genetic variability within and between populations. Small Ruminant Research, 43: 3-14.

Moce, M. L.; M. A. Santacreu; A. Climent and A. Blasco, (2004). The effect of divergent selection for uterine capacity on prenatal survival in rabbits: Maternal and embryonic genetic effects. J. Anim. Sci. 82:68-73.

Nyamsamba, D.; K. Noniura; M. Nozawa; K. Yokohama; Yo. Zagdsuren and T. Ainano, (2003). Genetic relationship among Mongolian native goat populations estimated by blood protein polymorphism. Small Ruminant Research, 47: 171- 181.

Peiro, R.; M. A. Santacreu; A. Climent and A. Blasco, (2007). Early embryonic survival and embryo development in two divergent lines selected for uterine capacity. J. Anim. Sci., 85:1634-1639.

Rangoju, P.K.; S. Kumar; A.P. Kolte; R. Gulyani and V.K. Singh, (2007). Assessment of genetic variability among rabbit breeds by random amplified polymorphic DNA (RAPD)-PCR. World Rabbit Sci., 15: 3 -8.

Rendo, F.; M. Iriondo; B. Jugo; A. Aguirre; L.I., Mazon; A. Vicario; M. Gomez and A. Estonba, (2004). Analysis of the genetic structure of endangered bovine breeds from the Western Pyrenees using DNA microsatellite markers. Biochem Genet., 42, 99-108.

Ryan, S.A. and W.R. Scowcroft, (1987). A somaclonal variant of wheat with additional B-amaylase isozymes. Theor. Appl. Genet., 73: 459-464.

Sax, K. (1923). The association of sizes differences with seed coat pattern and pigmentation in Phaseolus vulgarus. Genetics, 8, 552-560.

Scandalios, J. G. (1964). Tissue-specific isozyme variations in maize. J. of Heredity, 55: 281-285.

Teneva, A.; E. Todorovska; N. Tyufekchiev; L. Kozelov; A. Atanassov; S. Foteva; S. Ralcheva and S. Zlatarev, (2005). Molecular characterization of Bulgarian livestock genetic resources, I. Genetic diversity in Bulgarian Grey cattle as revealed by microsatellite markers. Biotechnology in Animal Husbandry, 21 (5- 6) 35-41.

Teneva, A.; E. Todorovska; N. Tyufekchiev; A. Stella; P. Boettcher and I. Dimitrova, (2007). Molecular characterization of Bulgarian livestock genetic resources. II. Microsatellite variation within and among Bulgarian cattle breeds. Biotechnology in Animal Husbandry, 23 (5-6) 227-242.

Teneva, A. and M. P. Petrović (2010). Application of molecular markers in livestock improvement. Biotechnology in Animal Husbandry 26 (3-4): 135-154.

Welsh, J. and MD. McClelland, (1990). Fingerprinting genomes using PCR with arbitrary primers. Nucleic Acids Research, 18(24), 7213-7218.

Williams, J.G.K.; A.R. Kubbelik; K.J. Livak; J.A. Rafalski and S.V. Tingey, (1990). DNA polymorphisms amplified by arbitrary primers are useful as genetic markers. Nucleic Acid Res., 18: 6531-5635.

Yang Yong; Zhu Qing and Hu Gang An, (2000). The use of microsatellite markers for detection of population genetic cariation in chicjen. Journal of sichuan university (natural science edition). 
Yang, W.; X. Kang; Q. Yang; Y. Lin and M. Fang, (2013). Review on the development of genotyping methods for assessing farm animal diversity. J. Anim. Sci. and Biotech, 4:2.

Zho, L.I.; Q. Haiguojin; I. Shaliguo and Y. Uhouwu; (2005). Genetic diversity analysis of five cattle breeds native to China using microsatellites. Journal of Genetics, 84 (1) 77-80.

$$
\begin{aligned}
& \text { تعريف التحسين الوراثي باستخدام المعلمـات الجزيئية الوراثية في بعض سـلالات }
\end{aligned}
$$

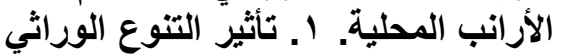

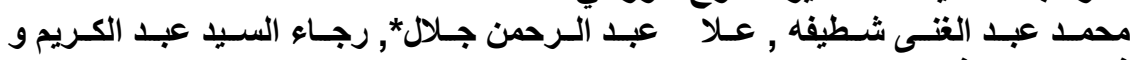

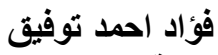

$$
\begin{aligned}
& \text { محطة بحوث الإتتاج الحيو اني بسخا ، معرد الزئ بحوث الإتتاج الحيواني ، مركز البحوث الزراعية }
\end{aligned}
$$

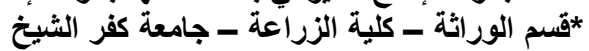

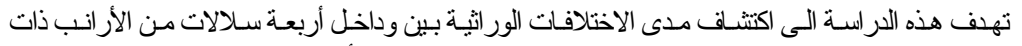

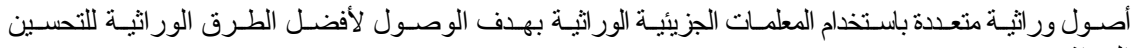

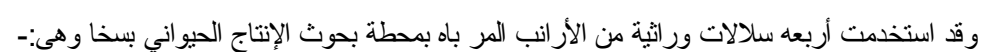

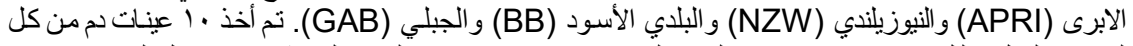

$$
\begin{aligned}
& \text { السلالات لعمل تحليل الايزوزيم باستخدام معلمات البروتين - SDS لاكتشاف التنتوع الوراثي بين وداخل السلالات تحت }
\end{aligned}
$$

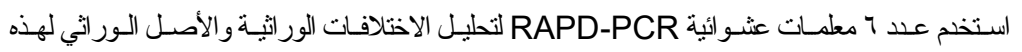

$$
\begin{aligned}
& \text { الراسة. }
\end{aligned}
$$

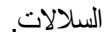

$$
\begin{aligned}
& \text { أوضحت النتائج المتحصل عليها ما يلى : } \\
& \text { • وجلت اختلافات متعدة في مستويات كل من البروتينات الموجودة والايزوزيم النشط. }
\end{aligned}
$$

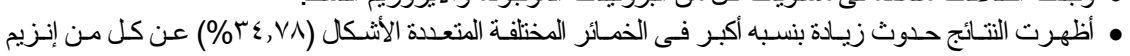

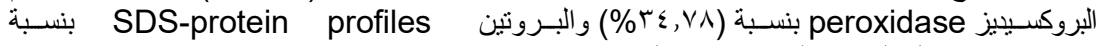

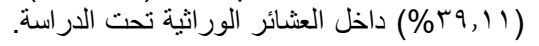

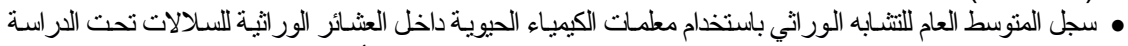

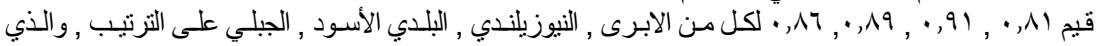

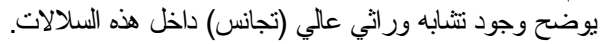

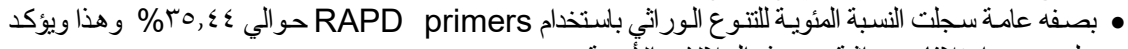

$$
\begin{aligned}
& \text { ملى وجود اختلافات وراثية بين هذه السلالات الأربعة. }
\end{aligned}
$$

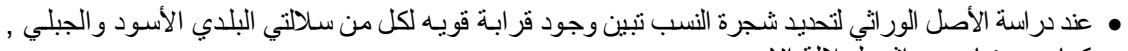

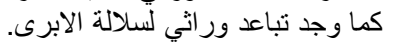

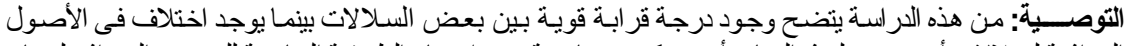

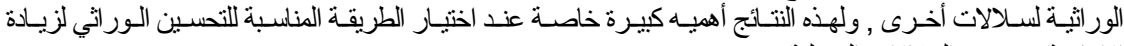

$$
\begin{aligned}
& \text { الإلتاجية وتحسين السلالات المختلفة. } \\
& \text { قام بتحكيم البحث }
\end{aligned}
$$

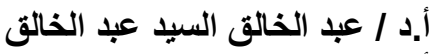

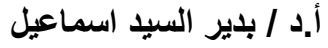

